\title{
MIKRODONTIA INSISIF LATERAL SEBAGAI SALAH SATU MANIFESTASI ORAL PENDERITA SINDROM DOWN TIPE MOSAIK DAN PENUH
}

\author{
Willyanti Syarif \\ Bagian Kedokteran Gigi Anak, Fakultas Kedokteran Gigi Universitas Padjadjaran
}

\begin{abstract}
ABSTRAK
Mikrodontia adalah kelainan ukuran gigi yang merupakan lebih kecilnya ukuran gigi dari normal disertai bentuk gigi yang mengerucut atau meruncing disebut conical teeth. Mikrodontia umumnya menyertai sindrom di antaranya sindrom Down. Tujuan penelitian ini adalah melihat manifestasi oral sindrom Down tipe mosaik dan penuh berdasarkan jumlah mikrodontia (conical teeth). Dilakukan studi kasus pada 33 penderita sindrom Down berusia 18-90 bulan yang terdiri dari 10 tipe mosaik dan 23 tipe penuh. Pemeriksaan gigi meliputi pemeriksaan bentuk dan ukuran gigi secara visual, dan disesuaikan dengan tabel ukuran gigi sulung menurut Wheeler. Hasil penelitian menunjukkan bahwa $6,1 \%$ penderita sindrom Down tipe mosaik dan penuh mempunyai mikrodontia insisif lateral sejumlah satu gigi, $3 \%$ penderita mosaik dan $45,5 \%$ penderita tipe penuh memiliki mikrodontia insisif lateral sejumlah lebih dari satu gigi. Mikrodontia insisif lateral pada gigi sulung lebih banyak terdapat pada penderita tipe penuh $(p=0,02)$. Hal ini menunjukkan bahwa hambatan pertumbuhan gigi pada anak sindrom Down tipe penuh lebih besar daripada tipe mosaik.
\end{abstract}

Kata kunci: Mikrodontia, sindrom Down mosaik, sindrom Down penuh

\section{INCISIVE LATERAL MICRODONTIA AS ORAL MANIFESTATION FOR FULL AND MOSAIC TYPE DOWN SYNDROME}

\begin{abstract}
Microdontia is the term when tooth size is smaller than normal, also called conical teeth. Etiology is multifactorial. Microdontia, commonly follow the syndromes. Down syndrome is common followed by microdontia. The aim of this study was to find out oral manifestation of mosaic and full trisomy based on the amount of microdontia in incisive lateral. Case study were done in 33 Down syndrome patients, aged 18-90 months consisted of 10 mosaic and 23 full types. Teeth examinations were done by visual examinations of size and form, and referred to Wheeler primary teeth table. The results showed $6.1 \%$ of mosaic and full trisomy have one conical teeth in insisifus lateral and $45.5 \%$ full trisomy and $3 \%$ mosaic have more than one conical teeth ini insisifus lateral. The percentage of the subject showed $60.60 \%$ had microdontia and $3.940 \%$ had normal size $(p=0.02)$. It is Significant that the conical teeth in full Down syndrome is more than mosaic patient. It shows that full type trisomy has more delayed teeth development.
\end{abstract}

Key words: Microdontia, mosaic, full Down syndrome

Alamat Korespondensi

Willyanti Syarif, drg., Sp.KGA

Bagian Kedokteran GigiAnak

Fakultas Kedokteran Gigi Universitas Padjadjaran

Jl. Sekeloa Selatan 1 Bandung

Telp, 0811200347 


\section{PENDAHULUAN}

Mikrodontia merupakan kelainan ukuran gigi yang menunjukkan ukuran gigi yang lebih kecil dari normal, dapat juga disertai kelainan bentuk yaitu dengan bentuk kerucut atau konus yang disebut juga conical teeth. Pada anak normal insidensnya adalah $0,2 \%$ pada gigi sulung dan gigi tetap. Umumnya keadaan ini terjadi pada gigi tetap, pada gigi sulung sangat jarang terjadi. Terdapat dua tipe mikrodontia yaitu tipe true microdontia dan pseudo microdontia. ${ }^{1}$ True microdontia adalah ukuran gigi yang lebih kecil dari normal pada rahang yang berukuran normal, sedangkan pseudo microdontia adalah seluruh gigi yang terlihat kecil pada rahang yang berukuran besar. Berdasarkan banyak gigi yang terkena dikenal ada localized microdontia dan generalized microdontia. True generalized microdontia adalah keadaan seluruh gigi berbentuk normal dengan ukuran lebih kecil dari normal, sedangkan generalized relative microdontia adalah seluruh gigi berukuran lebih kecil dari normal dengan rahang lebih besar dari normal. ${ }^{2}$ Generalize microdontia sangat jarang pada gigi sulung.

Etiologi mikrodontia adalah multifaktorial. Localized microdontia lebih sering terjadi biasanya berlokasi pada gigi insisif II sulung dan tetap, molar III tetap, biasanya diikuti dengan hipodontia. Mikrodontia terjadi sebagai akibat adanya disrupsi pada saat awal pertumbuhan dan perkembangan gigi yaitu pada tahap bud stage pada minggu kedelapan masa prenatal. Disrupsi perkembangan gigi mengakibatkan baik ameloblas dan odontoblas sebagai sel pembentuk gigi tidak berdiferensiasi optimal sehingga menghasilkan bentuk gigi yang lebih kecil dari normal. ${ }^{3} \mathrm{Hal}$ ini terjadi akibat kelainan genetik dengan interaksi faktor genetik dengan faktor lingkungan. Mikrodontia biasanya mengikuti beberapa sindrom. Sindrom yang disertai mikrodontia adalah sindrom Down, ektodermal displasia, Silver-Russel, William sindrom, Gorlin-Chaundhry Moss, dan CoffenSirin. Selain itu mikrodontia sering terlihat pada kasus cleft lip serta palatum dan umumnya mengenai gigi anterior terutama insisif.

Manifestasi klinis memperlihatkan ukuran mahkota yang lebih kecil, terutama insisif lateral lebih kecil daripada variasi normal disertai bentuk yang mengerucut atau conical teeth. Profil margin ginggiva terlihat lebih sempit dari normal. Mikrodontia lebih sering mengenai gigi anterior terutama insisif lateral dan pada jenis kelamin wanita lebih banyak daripada laki-laki.

Sindrom Down terdiri dari 3 (tiga) tipe, yaitu tipe penuh (full trisomy 21) (95\%), translokasi $(3-4 \%)$, dan mosaik (1-2\%). Tipe penuh adalah mayoritas sel mempunyai ekstrakromosom 21, sedangkan mosaik ialah bila ada sel yang mempunyai kromosom 47 dan mayoritas sel yang berkromosom 46. Jadi bentuk mosaik adalah suatu jenis dari kelainan antara sindrom Down dan normal. ${ }^{4,5}$

Penderita sindrom Down mempunyai tanda-tanda karakteristik orofasial seperti palatum tinggi, makroglosi, fisur dan geographic tongue, hipotonia otot-otot mulut, agenesis gigi, bentuk gigi lebih kecil atau konus, dan erupsi terlambat baik pada gigi sulung maupun gigi tetap. ${ }^{3-8}$

Penderita sindrom Down sering diikuti oleh adanya mikrodontia. Penelitian ini bertujuan untuk melihat karakteristik sindrom Down tipe mosaik dan penuh berdasarkan jumlah mikrodontia atau conical teeth.

\section{METODE}

Subjek adalah 33 pasien sindrom Down berusia 18 bulan sampai 90 bulan. Diagnosis sindrom Down dilakukan dengan pemeriksaan klinis dan analisis kromosom untuk menentukan kariotipe sindrom Down. Analisis kromosom dilakukan dengan karyotiping dan diagnosis trisomi 21 ditentukan apabila terdapat kromosom ekstra pada kromosom 21. Kriteria mosaik ditentukan apabila terdapat lebih dari $40 \%$ sel normal dan kriteria full trisomy (penuh) ditentukan apabila jumlah sel normal kurang dari $40 \%$.

Pemeriksaan gigi sulung meliputi pemeriksaan bentuk dan ukuran gigi yang ada. Ukuran dan bentuk gigi ini terlihat jelas secara klinis apakah lebih kecil atau berbentuk konus. Untuk menyakinkan ukuran gigi, mesodistal insisifus lateral diukur sliding kaliper dan diukur dengan mistar, setelah itu disesuaikan dengan tabel ukuran gigi dari Wheeler, ternyata ukuran itu jelas berbeda. ${ }^{10} \quad$ Penelitian ini tidak melakukan pencetakan gigi karena prosedur pencetakan gigi pada pasien ini cukup sulit karena biasanya harus disertai dengan sedasi atau anastesi umum.

\section{HASIL}

Penelitian menunjukkan dari 33 sindrom Down

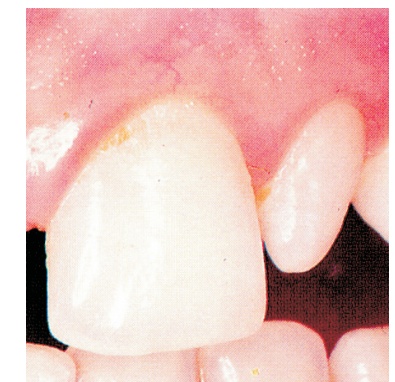

Gambar Gigi Insisif Lateral yang Mengalami Mikrodontia Sumber: Laskaris ${ }^{1}$ 
Tabel Distribusi Subjek Sindrom Down Tipe Mosaik dan Penuh Berdasarkan Gigi Jumlah Mikrodontia Insisif Lateral Sulung

\begin{tabular}{|c|c|c|c|c|}
\hline \multirow[b]{2}{*}{ Jenis Trisomi } & \multicolumn{3}{|c|}{ Bentuk gigi } & \multirow[b]{2}{*}{$\begin{array}{c}\text { Jumlah } \\
(\%)\end{array}$} \\
\hline & Normal & $\begin{array}{c}\mathrm{I}_{2} \\
\text { Konus } 1 \text { gigi }\end{array}$ & $\begin{array}{c}I_{2} \\
\text { Konus }>1 \text { gigi }\end{array}$ & \\
\hline Mosaik & $7(21,2)$ & $2(6,1)$ & $1(3,0)$ & $10(30,3)$ \\
\hline Penuh & $6(18,2)$ & $2(6,1)$ & $15(45,5)$ & $23(69,7)$ \\
\hline Jumlah & $13(39,4)$ & $4(12,1)$ & $16(48,5)$ & $33(100)$ \\
\hline
\end{tabular}

jumlah anak yang mengalami gigi konus adalah $20(60,60 \%)$, sedangkan yang mempunyai gigi normal adalah $13(39,4 \%)$. Di sini terlihat bahwa persentase anak yang mengalami gigi insisif II konus cukup tinggi.

Tabel menunjukkan bahwa dari 33 orang sindrom Down terdiri dari $10(30,3 \%)$ orang tipe mosaik dan $23(69,7 \%)$ orang tipe penuh. Di sini terlihat bahwa dari 10 orang tipe mosaik, tujuh orang mempunyai gigi normal, dua orang mempunyai mikrodontia insisif lateral, dan satu orang mempunyai mikrodontia insisif lateral lebih dari satu. Sedangkan dari 23 orang tipe penuh, enam orang mempunyai gigi normal, dua orang mempunyai satu mikrodontia insisif lateral, dan $15(45,5 \%)$ orang mempunyai gigi insisif lateral lebih dari satu gigi.

Hal ini memperlihatkan bahwa persentase anak tipe penuh mengalami gigi mikrodontia insisifus lateral lebih dari 1 gigi lebih banyak dibandingkan dengan tipe mosaik.

Dari tabel terlihat bahwa 13 orang $(39,4 \%)$ subjek mempunyai ukuran gigi normal sedangkan 20 orang $(60,6 \%)$ mempunyai gigi dengan mokrodontia insisif lateral konus. Sejumlah 15 orang $(45,5 \%)$ dengan tipe penuh mempunyai jumlah mikrodontia insisif lateral lebih dari dua gigi. Tipe mosaik memperlihatkan jumlah mikrodontia insisif lateral lebih sedikit dari tipe penuh, ini terlihat pada dua orang $(6,1 \%)$ mempunyai mikrodontia insisif lateral satu gigi dan satu orang $(3,0 \%)$ mempunyai mikrodontia insisif lateral insisif lebih dari satu gigi.

\section{PEMBAHASAN}

Menurut Laskaris ${ }^{1}$ persentase kejadian mikrodontia pada anak normal adalah $0,2 \%$ pada gigi tetap dan gigi sulung, umumnya gigi yang sering terkena adalah insisifus lateral sulung tetap dan molar 3 tetap.

$$
\text { Etiologi mikrodontia adalah }
$$

multifaktorial, keturunan, dan sering kali mengikuti berbagai sindrom. Mikrodontia adalah kelainan yang disebabkan adanya disrupsi tumbuh kembang gigi. Disrupsi tumbuh kembang gigi ini disebabkan oleh adanya gangguan faktor sistemik dan genetik, dalam hal ini adalah kelainan kromosom 21. Mirkodontia terjadi sebagai akibat adanya gangguan tahap bud stage yaitu saat embrio berusia 8 minggu, yaitu terjadinya obstruksi lamina dentalis sehingga terjadi gangguan proliferasi dari bakal ameloblas dan odontoblas. Gangguan proliferasi ini mengakibatkan penyimpangan diferensiasi sel-sel bakal ameloblas pembentuk email dan odontoblas pembentuk dentin sehingga keadaan ini menghasilkan bentuk gigi yang tidak sempurna atau mempunyai ukuran mesodistal lebih kecil dari normal. ${ }^{10}$ Pada penderita sindrom Down ternyata mikrondontia banyak ditemukan baik pada tipe penuh maupun mosaik. Hal ini disebabkan karena adanya delayed teeth development pada penderita sindrom Down khususnya tipe penuh lebih daripada tipe mosaik. Tipe mosaik mempunyai kelainan klinis yang lebih ringan daripada tipe penuh.

Sebanyak $35 \%$ penderita sindrom Down mempunyai bentuk dan ukuran gigi insisif 2 lebih kecil dari normal terutama pada insisif lateral sehingga terjadi diastema. ${ }^{7}$

Pada penelitian ini $60,6 \%$ mengalami insisif 2 konus. Penelitian ini menunjukkan bahwa 15 orang sindrom Down tipe penuh mengalami ukuran gigi dan bentuk gigi lebih kecil daripada normal lebih dari satu gigi dan cenderung mempunyai jumlah mikrodontia atau gigi dengan ukuran lebih kecil lebih banyak daripada tipe mosaik. Hal ini sesuai dengan pendapat Lowitz dan Mark, ${ }^{6}$ Desai ${ }^{7}$ bahwa kelainan pada tipe mosaik lebih ringan daripada tipe penuh. Menurut Nowak dan Arthur ${ }^{11}$ gigi anterior rahang bawah lebih tajam (konus) dan lebih kecil dibanding anak normal.

Mikrodontia pada insisif 2 merupakan salah satu manifestasi oral penderita sindrom Down baik pada tipe penuh maupun mosaik. Pada tipe penuh jumlahnya lebih banyak daripada tipe mosaik.

\section{DAFTAR PUSTAKA}

1. Laskaris G. Color atlas of oral disease in children and adolescents. New York: 2000.

2. Cameron A, Widmer R. Handbook of pediatric dentistry. London: Mosby; 1998.

3. Limbrock, Fischer-Brandies $\mathrm{H}$, Avalle $\mathrm{C}$, Morales C. Orofasial therapy-treatment of 67 
children with Down syndrome. Dev Med Child Newrol. 1991;33:196-303.

4. Smith, Wilson. The child with sindrom Down. Philadelphia: WB Saunders Company; 1973.

5. Jones $\mathrm{KL}$. Morphogenesis and dysmorfogenesis smith recognizable pattern of human malformation. Edisi ke-5. Philadelphia: WB Saunders Co; 1997.

6. Lowitz S, Mark. Down syndrome: the facts. Edisi ke-2. New York: Oxford University Press Inc; 1997.

7. Desai SS. Down syndrome. A review of the literature, oral surgery, oral medicine, oral pathology, oral radiology and endodonties. J Pediatric Health Care. 1997 September; 84(3):279-85.

8. Welburry RR. Paediatric dentistry. Edisi ke-2. New York: Oxford Medical Publication; 2001.

9. Sjarif W, Oewen R. Down syndrome perspective pediatric dentistry, Indonesia Dental Ass. 2003 September:150-4.

10. Balogh MB, Fehrenbach MJ. Dental embryology, histology, and anatomy. Edisi ke2. St Louis: Elsevier Saunders; 2006.

11. Nowak, Arthur J. Dentistry for the handicapped patient. Saint Louis: C.V Mosby; 1976. 